NBER WORKING PAPER SERIES

\title{
GLOBAL TRANSMISSION OF INTEREST RATES: MONETARY INDEPENDENCE AND CURRENCY REGIME
}

\author{
Jeffrey A. Frankel \\ Sergio L. Schmukler \\ Luis Servén \\ Working Paper 8828 \\ http://www.nber.org/papers/w8828 \\ NATIONAL BUREAU OF ECONOMIC RESEARCH \\ 1050 Massachusetts Avenue \\ Cambridge, MA 02138 \\ March 2002
}

We are grateful to Michael Melvin, Jorge Streb, three anonymous referees, and participants at the Universidad T. Di Tella-World Bank conference on currency regimes for very useful comments. We thank Andrea Bubula, Tatiana Didier, Eduardo Fajnzylber, Changqing Sun, Nong Thaicharoen, Hairong Yu, and particularly Yanchun Zhang for excellent research assistance. We also thank Atish Ghosh, Eduardo Levy Yeyati, Federico Sturzenegger, and Hoger Wolf for generously providing us with their data. The World Bank Latin American and the Caribbean Regional Studies Program provided financial support for this research. The views expressed herein are those of the authors and not necessarily those of the National Bureau of Economic Research, the World Bank, its Executive Directors, or the countries they represent.

(C) 2002 by Jeffrey A. Frankel, Sergio L. Schmukler and Luis Servén. All rights reserved. Short sections of text, not to exceed two paragraphs, may be quoted without explicit permission provided that full credit, including (C) notice, is given to the source. 
Global Transmission of Interest Rates:

Monetary Independence and Currency Regime

Jeffrey A. Frankel, Sergio L. Schmukler and Luis Servén

NBER Working Paper No. 8828

March 2002

JEL No. F31, F32, F33, F36

\begin{abstract}
Using a large sample of developing and industrialized economies during 1970-1999, this paper explores whether the choice of exchange rate regime affects the sensitivity of local interest rates to international interest rates. In most cases, we cannot reject full transmission of international interest rates in the long run, even for countries with floating regimes. Only large industrial countries can benefit, or choose to benefit, from independent monetary policy. However, short-run effects differ across regimes. Dynamic estimates show that interest rates of countries with more flexible regimes adjust more slowly to changes in international rates.
\end{abstract}

Jeffrey A. Frankel

Harvard University

79 JFK St.

Cambridge, MA 02138-5801

and NBER

jeffrey_frankel@harvard.edu
Sergio L. Schmukler

World Bank

1818 H. St. NW

Washington, DC 20433

sschmukler@worldbank.org
Luis Servén

World Bank

1818 H. St. NW

Washington, DC 20433

lserven@worldbank.org 


\section{Global Transmission of Interest Rates: Monetary Independence and Currency Regime}

\section{Introduction}

Changes in interest rates in major countries tend to have important effects on other countries. For example, as has also been true in past episodes of global monetary tightening, the 1999-2000 hikes in U.S. interest rates were rapidly reflected in interest rate increases in other industrial and developing economies. In emerging markets, the increases were in several cases proportionally larger than those experienced in the U.S., presumably because country and/or currency risks increased after the Fed decided to tighten U.S. monetary policy. Even though the pressure to increase interest rates was felt virtually across the board, one question remains unanswered: are countries with flexible exchange rates more able to isolate their domestic interest rates from this type of negative international shock? This issue of monetary independence, which lies at the heart of the debate on currency arrangements, is the central question of this paper.

The choice of exchange rate regime - floating, fixed, or somewhere in between has been a recurrent question in international monetary economics. According to the conventional view, the two major advantages of fixing the exchange rate are: (1) reduced transactions costs and exchange rate risk, that can discourage trade and investment, and (2) a credible nominal anchor for monetary policy.

The advantages of a flexible exchange rate, on the other hand, can generally be described under one major property: it allows the country to pursue independent 
monetary policy. ${ }^{1}$ The argument in favor of monetary independence, instead of constraining monetary policy by the fixed exchange rate, is the classic argument for discretion instead of rules. When the economy is hit by a disturbance, such as a shift in worldwide demand away from the goods it produces, the government would like to be able to respond, so that the country does not go into recession. Under fixed exchange rates, monetary policy is always diverted, at least to some extent, to dealing with the balance of payments. Under the combination of fixed exchange rates and complete integration of financial markets, which characterizes the European monetary union, monetary policy becomes completely powerless. ${ }^{2}$ By freeing up the currency, on the other hand, the country can respond to a recession by means of monetary expansion and depreciation of the currency. This stimulates demand for domestic products and returns the economy to desired levels of employment and output, more rapidly than would be the case under the automatic mechanisms of adjustment on which a fixed-rate country must rely. $^{3}$

According to the traditional arguments, under pegged exchange rates and unrestricted capital flows, domestic interest rates cannot be set independently, but rather must track closely those prevailing in the country to which the domestic currency is pegged. By contrast, under a flexible exchange rate arrangement, the domestic interest

\footnotetext{
${ }^{1}$ To be sure, other factors enter as well. Two other advantages of an independent currency are that the government retains seignorage, and floating allows smooth adjustment to real shocks even in the presence of price frictions. Most of the important factors, however, can be lumped into the major arguments presented in the text.

${ }^{2}$ An expansion in the money supply has no effect: the new money flows out of the country, via a balance of payments deficit, just as quickly as it is created. In the face of an adverse disturbance, the country must simply live with the effects. After a fall in demand, for example, the recession may last until wages and prices are bid down, or until some other automatic mechanism of adjustment takes hold.

${ }^{3}$ For a more complete exposition of the advantages and disadvantages of alternative exchange rate regimes, see Frankel, Schmukler, and Servén (2001).
} 
rate should be less sensitive to changes in international interest rates - other things equal. Countries with intermediate regimes should also display less sensitivity to international interest rates than countries with firm pegs.

Despite these predictions, an alternative view - stated, among others, by Calvo and Reinhart (2001 and 2002) and Hausmann, Panizza, and Stein (2001) - holds that there exists "fear of floating," that prevents countries with de jure flexible regimes from allowing their exchange rates to move freely. According to this view, factors like lack of credibility, exchange rate pass-through, and foreign-currency liabilities prevent countries from pursuing an independent monetary policy, regardless of their announced regime. Therefore, many countries, even if formally floating, are de facto "importing" the monetary policy of major-currency countries, much as those with pegs. It has even been suggested that interest rates might sometimes be more sensitive to U.S. rates in flexiblerate developing countries than in fixed-rate countries, because flexible-rate developing countries suffer from having to pay risk premia (both currency premia to compensate for devaluation risk and country premia to compensate for default risk) and because these premia may be sensitive to world interest rates.

Although monetary independence has been at the heart of the debate on exchange rate regimes, empirical evidence on the issue is still scarce. In particular, there are few empirical studies on whether floating exchange rate regimes do indeed allow independent monetary policy, in the sense that interest rates in countries with floating regimes are less sensitive to foreign interest rates. Focusing on some countries whose regimes can be clearly defined as either currency boards or floating regimes (such as those in Argentina, Mexico, Hong Kong, and Singapore), Borensztein, Zettlemeyer, and Philippon (2001) 
find some evidence consistent with the traditional view. This study is particularly interesting because it makes a particular effort to identify the response of interest rates to exogenous shocks in world interest rates. On the other hand, selected country evidence during the 1990s - reported in Frankel (1999) and Hausmann, Gavin, Pages, and Stein (1999) - is consistent with the alternative view.

The goal of this paper is to establish major empirical regularities concerning the sensitivity of domestic interest rates to international interest rates under different currency regimes. To do this, we analyze the widest possible spectrum of regimes, from full exchange rate flexibility to currency boards. Thus, the paper should help place the ongoing debate in the context of the observed facts, and allow an assessment of the competing claims cited above on the relative merits of alternative exchange rate arrangements from the perspective of monetary independence. ${ }^{4}$

The paper extends the empirical literature in several directions. First, while previous studies have been limited to a handful of countries over short time periods, here we consider a much larger data set in both the cross-country and time-series dimensions, by working with a sample of industrial and developing countries over the last three decades. Second, we study both the long-run transmission of interest rates and their dynamic adjustment under different exchange rate regimes. Third, we test the robustness of the results to changes in sample period, empirical specification, and exchange rate regime classification system. Finally, even though we work mainly with U.S. rates as our primary indicator of "foreign interest rates," we also take into account the emergence in

\footnotetext{
${ }^{4}$ There is an extensive empirical literature that studies the merits of different exchange rate regimes in other dimensions. For example, Ghosh, Gulde, Ostry, and Wolf (1996) analyze the behavior of inflation and growth under alternative exchange rate arrangements. Also, a related literature studies
} 
recent years of other currency areas, most notably the Deutsche mark-European Monetary Union (DM-EMU) zone. Thus, we examine the sensitivity of European interest rates to German interest rates.

The rest of the paper is organized as follows. Section 2 introduces the methodology and data used in this paper. Section 3 presents pooled estimation results by exchange rate regime, income group, and decade. Section 4 presents individual-country dynamic estimates for the 1990s. Section 5 summarizes the results and concludes. The Appendix describes the exchange rate regimes in each country in the sample.

\section{Methodology and Data}

\subsection{Methodology}

In principle, there are several factors that determine the extent to which domestic and foreign interest rates move together. The first one is the degree of financial integration of the domestic economy into world markets. Barriers to international capital flows can dampen the response of local rates to changes in international rates, allowing monetary authorities in different countries to maintain different interest rate levels for extended periods, even under fixed exchange rates. Second, the degree of real international integration also affects the comovement of domestic and foreign interest rates: if business cycles are highly synchronized across countries, domestic and foreign rates will tend to move closely together, given other things. Third, the nature of shocks also contributes to determine the degree of comovement. Unlike country-specific idiosyncratic shocks, common shocks - such as financial and climatic - affect many 
countries simultaneously, which tend to be reflected in closer correlation of interest rates for given degrees of international real and financial integration.

Thus, monetary authorities otherwise able to develop independent monetary policy are likely to choose similar policy stances - and hence similar interest rate patterns - if the degree of international business cycle synchronization is high, and/or their respective economies are subject to common shocks more often than not. In other words, even under full monetary independence the observed path of interest rates will differ across countries only to the extent that their authorities choose to pursue different monetary policies.

Notwithstanding these considerations, our primary concern here is to establish the empirical regularities regarding the observed link between local and foreign interest rates, rather than sorting out the role of each of the above factors. Thus, our starting point is the empirical estimation of a simple reduced-form specification using panel data:

$$
r_{i, t}^{l c}=f_{i}+\beta r_{t}^{*}+\gamma^{\prime} X_{i, t}+\varepsilon_{i, t},
$$

where $i=1, \ldots, N$ and $t=1, \ldots, T$ respectively denote countries and time periods. Here $r_{i, t}^{l c}$ represents the domestic nominal interest rate in local currency of country $i$ at time $t ; f_{i}$ is a country-specific effect; ${ }^{5} r_{t}^{*}$ is the international interest rate; and $X_{i, t}$ is a set of control variables. We assume that the error term $\varepsilon_{i, t}$ has mean zero and is independently distributed across countries, but is possibly heteroskedastic and serially correlated.

In our basic panel specification we include no control variables (i.e., we drop $X_{i t}$ from (1)). As a robustness check, however, we repeated our empirical experiments including as control variable the difference between the domestic and foreign inflation 
rates. $^{6}$ We do this because much of the variation in nominal interest rates, across countries and over time, could just reflect variation in currency (and/or country) risk premia, both of which might be proxied by inflation differentials. ${ }^{7}$ However, adding the inflation differential to our specification (1) causes virtually no change in the empirical estimates, and thus to save space we only report a subset of the inflation-inclusive experiments below.

As a further robustness check, we also added into $X_{i, t}$ a set of dummy variables to control for turbulent periods, when the sensitivity of local interest rates to foreign ones may differ from its "normal" value. Specifically, we used three dummies. The first one is a "crisis" dummy constructed along the lines of the literature on exchange rate crises. The second is a hyperinflation dummy, equal to one when monthly inflation is above 50 percent. Finally, the third is a "transition" dummy to control for changes in the exchange rate regime - specifically, exit from pegs to other regimes. ${ }^{9}$ Further, to allow some additional flexibility in our specification we also interacted the three dummies with the

${ }^{5}$ Note that time-specific effects cannot be included, because they would be perfectly collinear with $r_{t}^{*}$.

${ }^{6}$ All interest rates and inflation rates $z$ are defined as $\ln (1+z)$. We also experimented with a somewhat more general version including separately domestic and foreign inflation, rather than entering them as a differential. Results with this broader specification, however, showed that in general the differential specification was not rejected by the data.

${ }^{7}$ For example, the currency premium could reflect anticipations of devaluation, which is customarily assumed to depend on inflation differentials. The country premium might reflect overall economic instability, which in empirical studies is often summarized by the inflation rate.

${ }^{8}$ Specifically, it takes a value of one when the cumulative depreciation of the nominal exchange rate over a three-month period is equal to or greater than 15 percent. We tried different variations with higher and lower depreciation thresholds and periods, without any material effect on the empirical results.

${ }^{9}$ Since such exits tend to be accompanied by considerable financial turbulence, in the absence of controls the new regime may be unduly associated with higher or more volatile interest rates and inflation, as noted by Edwards and Savastano (1999). The transition dummy takes a value of one in the month of the transition as well as those immediately preceding and following it. In other specifications, we experimented with longer transition periods and also dropping the corresponding observations. These alternative specifications had only a very modest impact on the parameter estimates of equation (1). 
foreign interest rate. On the whole, the empirical results obtained from these experiments were quite similar to those from the basic specification without controls, and hence to save space they are not reported below. ${ }^{10}$

We estimate equation (1) separately for each currency regime, since preliminary evidence showed that neither the country effects nor the coefficients on the control variables were equal across regimes. For each regime, we are interested in two parameters, characterizing respectively the sensitivity of the local interest rate to the foreign rate ( $\beta$ in equation (1) above), and the average level of the local interest rate (after controlling for the foreign interest rate). The latter can be summarized by a parameter $\alpha$, defined as:

$$
\alpha=\frac{1}{N} \sum_{i=1}^{N} f_{i}
$$

that is, the average of the country-specific effects under the regime in question. ${ }^{11}$

In section 3 we report pooled estimates of $\alpha$ and $\beta$ obtained on the full sample, as well as grouping countries by per-capita income level and breaking the sample by decade (1970s, 1980s, and 1990s), to see if there are any significant differences along these dimensions.

According to conventional wisdom, more flexible exchange rate regimes should allow countries additional room to pursue their independent monetary policy. Therefore, the sensitivity of local to international interest rates should increase with the rigidity of

\footnotetext{
${ }^{10}$ Those results are available upon request and downloadable from www.worldbank.org/lacconferences.

${ }^{11}$ Strictly speaking, this definition would apply if under each exchange rate regime all countries possessed the same number of time-series observations. In practice, this is not the case because our panel is unbalanced. The formula then is amended using weights given by the respective number of observations.
} 
the exchange rate regime. In other words, for a given degree of capital mobility, real integration, and other factors, we would expect $\left.\left.\beta_{\text {fixed }}\right\rangle \beta_{\text {intermediate }}\right\rangle \beta_{\text {floating }}$. In fact, in a fixed exchange rate regime with full capital mobility we should expect $\beta_{\text {fixed }}=1$. At the opposite extreme, we would expect $\beta_{\text {floating }}\langle 1$, except in the unlikely case that the monetary authorities in floating exchange rate countries happen to choose the same monetary policy rule as the world at large, and their economies exhibit perfectly correlated business cycles (or are subject only to common shocks). In the case of floating regimes, the exchange rate bears the burden of absorbing the shocks to international interest rates. In the case of intermediate regimes, including "dirty floating" arrangements, the exchange rate absorbs less of the international shocks, so local interest rates move more closely together with those abroad. Thus, we expect $\left.\beta_{\text {fixed }}\right\rangle \beta_{\text {intermediate }}$.

The country-specific effect $f_{i}$ measures, for each country and under each regime, the average level of the interest rate not accounted for by foreign interest rates (and the inflation differential when included in the equation). Hence, $f_{i}$ may be viewed as reflecting the mean level of currency premium and country premium not captured by other variables. The average of the country-specific effects under each regime ( $\alpha$ as defined earlier) can then be interpreted as a measure of the regime's mean currency premium plus country premium under the null of $\beta=1$. Thus, if for example more rigidly fixed exchange rate regimes reduce devaluation expectations, for given country risk perceptions and levels of $\beta$ we should obtain $\alpha_{\text {fixed }}\left\langle\alpha_{\text {intermediate }}\left\langle\alpha_{\text {floating }}\right.\right.$. 
Equation (1) involves no dynamics, and hence it might be viewed as describing the long-run relation between domestic and foreign interest rates. ${ }^{12}$ However, it may be argued that the issue of monetary independence has at least as much to do with the shortrun adjustment of interest rates as with the long-run effect. Countries might not be able to isolate themselves from fluctuations in world interest rates in the long run, but might be able to do so temporarily. The degree of monetary autonomy would then be measured by the length of time until full adjustment of the local interest rate to its foreign counterpart.

To assess the dynamics of interest rate adjustment, we employ a dynamic version of (1) including lags of the dependent and independent variables. Our starting point is Hendry's GUM (general unrestricted model) specification describing the local interest rate of a given country:

$$
r_{t}^{l c}=\alpha_{0}+\sum_{p=1}^{P+1} d_{p} r_{t-p}^{l c}+\sum_{k=0}^{Q+1} b_{k} r_{t-k}^{*}+\sum_{l=0}^{Q+1} g_{l}{ }^{\prime} X_{t-l}+u_{t}
$$

This is just an unrestricted autoregressive-distributed lag (ARDL) model of order $(P+1, Q+1)$. With some straightforward manipulations, it can be rewritten as

$$
\Delta r_{t}^{l c}=\sum_{p=1}^{P} D_{p} \Delta r_{t-p}^{l c}+\sum_{k=0}^{Q} B_{k} \Delta r_{t-k}^{*}+\sum_{l=0}^{Q} G_{l}{ }^{\prime} \Delta X_{t-l}-\delta\left[r_{t-1}^{l c}-f_{0}-\beta r_{t-1}^{*}-\gamma^{\prime} X_{t-1}\right]+u_{t}
$$

Equation (4) is written in error-correction form, with the "long-run" solution given by the term in square brackets in the right-hand side, analogous to (1) above. ${ }^{13}$ The

\footnotetext{
${ }^{12}$ In fact, this would be precisely the case in a panel cointegration context if domestic and foreign interest rates were non-stationary (but cointegrated); see Baltagi (2000).

13 Note that a long-run equilibrium relation among the variables of interest may exist irrespective of whether they are I(0) or I(1); see Pesaran (1997).
} 
speed of adjustment towards the long-run equilibrium is measured by the parameter $\delta=1-\left(\sum_{p=1}^{P} d_{p}\right)$, and we have defined $f_{0}=\frac{\alpha_{0}}{\delta}, \beta=\frac{\sum_{k=1}^{Q} b_{k}}{\delta}$, and $\gamma=\frac{\sum_{l=1}^{Q} g_{l}}{\delta}$.

Other things equal, for the reasons already mentioned above we would expect a systematic association between the speed of adjustment $\delta$ and the exchange rate regime - i.e., $\left.\left.\delta_{\text {fixed }}\right\rangle \delta_{\text {intermediate }}\right\rangle \delta_{\text {floating }}$. Indeed, with no barriers to capital movements we should find $\delta \rightarrow 1$ under fixed exchange rates. Conversely, with flexible exchange rates and national authorities exercising independent monetary policy we should find much lower values of $\delta$. In the limit, with full independence we would expect to find $\delta \rightarrow 0$, so that the local interest rate does not revert to a long-run equilibrium relation with the foreign interest rate.

Rather than pooling the data, we estimate the dynamic specification (4) separately for each country-currency regime episode in the sample. The reason is that even under cross-country regime homogeneity of the long-run parameters (e.g., full adjustment of local to foreign interest rates in the long run under every currency regime), heterogeneity in the adjustment dynamics may exist among countries with similar exchange rate regimes due to factors such as the degree of development of the financial system and the openness of the capital account. Pooled estimation of (4) would then yield inconsistent estimates (Pesaran and Smith 1995). 
Our approach to the estimation of (4) departs from the recent cointegration literature and thus does not require pre-testing for order-of-integration conformability. ${ }^{14}$ Specifically, if the disturbance $u_{t}$ is serially uncorrelated (which basically requires sufficiently long lag orders $P$ and/or $Q$ ) and at most one long-run relation exists among $r^{l c}, r^{*}$, and $X$, the speed of adjustment $\delta$ and the long-run parameters can be jointly estimated by ordinary least squares (OLS), regardless of whether the variables are $\mathrm{I}(0)$ or $\mathrm{I}(1) .^{15}$

Moreover, in the framework of equation (4) testing the null hypothesis that no long-run relation exists among $r^{l c}, r^{*}$, and $X$ is equivalent to testing the null hypothesis $\delta=0$; see Pesaran, Shin, and Smith (2001). The test can be based on the magnitude of the t-statistic of $\delta$ obtained from OLS estimation of (4), and is valid regardless of whether the variables are $\mathrm{I}(0)$ or $\mathrm{I}(1)$. However, the applicable critical values are different in both scenarios, with that for the $\mathrm{I}(1)$ case lying above the one for the $\mathrm{I}(0)$ case. Hence, if the t-statistic of $\delta$ exceeds the former critical value, the null of no longrun relation can be unambiguously rejected; while if it falls short of the latter critical value, the null of no long-run relation cannot be rejected regardless of the order of integration of the variables. If the statistic falls between the two critical values, then the evidence is inconclusive, and existence of a long-run relation depends on the order of integration of the variables. ${ }^{16}$

\footnotetext{
${ }^{14}$ These pre-testing procedures face more often than not the problem of low power of standard unit root tests. In our case, a priori we would expect interest rates to be $\mathrm{I}(0)$ variables, as noted by Cochrane (1991). However, this is inessential for our estimation procedure.

15 See Banerjee et al. (1993), Boswijk (1995), and Pesaran and Shin (1999). Estimates of the standard errors of the long-run parameters can be computed along the lines of Bardsen (1989).

${ }^{16}$ The critical values we use are taken from Table C2.iii in Pesaran, Shin, and Smith (2001).
} 
In our basic dynamic specification, we let $X$ equal the inflation differential but set $\gamma=0$, while allowing for $B_{k} \neq 0$. In other words, we let the inflation differential affect the dynamic adjustment but not the long-run equilibrium, which is therefore analogous to equation (1) above. However, we also repeated our estimations imposing both $\gamma=0$ and $B_{k}=0$, as well as allowing for both $\gamma \neq 0$ and $B_{k} \neq 0$. In both cases, the results were virtually identical to those obtained with the basic specification, and hence to save space they are not reported below. ${ }^{17}$

\subsection{Data}

Our basic source of interest rate data is the International Financial Statistics of the International Monetary Fund (IMF). We work with monthly data on 90-day local money market rates for the 1970s, 1980s, and 1990s. We choose money market interest rates because they reflect market forces better than deposit rates. The latter, while much more widely available, are often subject to administrative controls and in many cases display little movement over prolonged periods, which renders them uninformative for our purposes. ${ }^{18}$ As international interest rate, we use the 90-day U.S. T-bill rate but, as we shall discuss below, for some experiments we use also the German 90-day T-bill rate. ${ }^{19}$

Our classification of exchange rate regimes is based on a quarterly database from the IMF which encompasses a total of ten regime categories, based on officially reported

\footnotetext{
17 These additional results are available upon request.

${ }^{18}$ In a number of cases we found that the money market interest rate data from IFS were identical to the deposit data. In such cases, we discarded countries/periods for which rates showed no variation or infrequent step-wise movements.

${ }^{19}$ We also experimented with the U.S. LIBOR dollar rate. The results were very similar, since the two rates are very highly correlated
} 
exchange arrangements for the period 1975-1996. The Appendix lists the regimes prevailing in each country over the sample period according to this source. We present some empirical results (in Table 1 below) from estimating equation (1) using the detailed regime categories in the original source. However, to simplify the analysis, in the rest of our experiments we condense these categories into three broader exchange rate regimes: fixed (pegs), intermediate (limited flexibility, crawls, bands, managed floating), and flexible (free-floating).

To assess the robustness of our results, we repeated our empirical estimations using two alternative classifications. The first one is that of Levy Yeyati and Sturzenegger (2000), who propose a de facto classification based on actual data on exchange rates and reserves, which is fairly different from the IMF-based one because the latter reflects de jure information supplied by domestic monetary authorities. Below we report a set of empirical results based on this alternative classification. The second alternative classification is that of Ghosh, Gulde, Ostry, and Wolf (1996). Results using this latter option were quite similar to those obtained using the IMF-based classification, so we do not report them to save space.

The rest of our data - exchange rates, inflation, and country indicators, such as population and income level on which the sample selection is based - come from the World Bank-IMF databases.

We focus on industrial economies and middle-income developing countries. Within this broad group, sample coverage is dictated by the availability of adequate interest rate data. ${ }^{20}$ The sample that results comprises 46 countries (18 industrial and 28

\footnotetext{
${ }^{20}$ We dropped country-regime episodes possessing less than one year of consecutive monthly observations. We also excluded countries with population under one million, countries without availability of long
} 
developing) in addition to the U.S. (whose interest rate is used as an explanatory variable) and a total number of monthly observations exceeding 9,300 .

\section{Interest Rate Sensitivity: Pooled Estimates}

We first assess empirically the sensitivity of domestic interest rates to international interest rates by estimating equation (1) using the entire sample, as well as distinguishing between industrial and developing countries and considering subsamples defined by time period.

Table 1 presents the full-sample fixed-effects estimation results, using a fiveregime classification of currency arrangements. For each regime, we report the slope parameter $\beta$ and the level parameter $\alpha$ defined earlier, as well as the p-value from the test of the null hypothesis $\beta=1$. The table shows the results obtained estimating separate panels by exchange rate regime. Taken at face value, the slope coefficient estimates show only modest numerical differences across regimes, although strictly speaking they seem to conform to conventional wisdom: the point estimate is higher (at 0.62) under pegged regimes than under intermediate and floating regimes (both equal to 0.53). Indeed, for pegged regimes the slope estimate is not statistically different from unity and this applies whether the peg is to the U.S. dollar or to other currencies (although in the former case the slope estimate is quite imprecise and insignificantly different from zero as well). Among intermediate regimes, there is a contrast between bands, which

exchange rate series (which automatically leads to the exclusion of Eastern European economies), low-income countries (in which the incidence of interest rate controls is more widespread), and countries with prolonged internal or external war periods. 
show a slope estimate similar to that of pegged regimes (0.60) and managed floats, whose slope coefficient is estimated imprecisely and is not significantly different from zero.

The estimated constants under each regime also deserve mention. As noted earlier, they could be viewed as reflecting the level of the domestic interest rate characteristic of each regime, after removing the effects of international interest rates. The table shows that, given other things, the level of local interest rates is lowest under fixed exchange rate arrangements - and among these, non-dollar pegs exhibit the lowest interest rate levels. At the other extreme, floating and managed floating regimes tend to exhibit the highest interest rate levels, given other factors.

Unlike the differences in slopes, these differences in constant terms across regimes are highly significant statistically. One-sided Wald tests confirm that the constant for fixed regimes is lower than the constant for intermediate regimes (the pvalue for the null that $\alpha_{\text {fixed }}>\alpha_{\text {intermediate }}$ is less than .001) and that the constant for intermediate regimes is lower than the constant for floating regimes (the statistic for the null $\alpha_{\text {intermediate }}>\alpha_{\text {floating }}$ yields a p-value of .003). Moreover, these tests yield the same conclusion if we use alternative regime classifications and/or alternative specifications of equation (1) adding the controls described earlier. In sum, the Wald tests do suggest that more flexible regimes tend to have higher interest rates. ${ }^{21}$

In spite of the simplicity of the specification and the fairly large sample sizes, our estimated equations capture a considerable amount of the observed variation in interest rates, as shown by the $\mathrm{R}^{2}$ statistics in the table.

\footnotetext{
${ }^{21}$ Interestingly, this does not appear to result from lower average inflation in fixed regimes than the rest: the same result is found if we add inflation differentials to the estimated specification.
} 
The above estimates pool for each regime all countries and time periods. However, a closer look seems warranted, because the underlying data may conceal a considerable degree of heterogeneity along two major dimensions. First, the overall sample includes countries with very diverse degrees of economic and financial development. Specifically, industrial countries are financially more stable, and tend to possess stronger and more credible institutions than developing countries. These factors may allow them to pursue an independent monetary policy to a larger extent than developing economies.

Second, the long time span of the full sample may conceal significant variation over time in the sensitivity of domestic to foreign interest rates, as barriers to international capital movements have declined steadily over the last two decades. Restrictions to capital movements were commonplace during the 1970s. In the 1980s, many countries, especially developed nations, started removing barriers to capital flows and liberalizing their financial systems. By the beginning of the 1990s, most developed and developing countries had already liberalized their financial sectors. ${ }^{22}$ The increasing degree of financial liberalization likely enhanced the comovement of domestic and international interest rates, as shown in Kaminsky and Schmukler (2001).

A third, more specific issue concerns the evolution of monetary arrangements in most of Western Europe, which in the late 1980s and 1990s assigned to the DM the role of hegemonic currency. For the countries involved in the DM (now EMU) zone of influence, German interest rates likely provide a measure of international rates more relevant than the U.S. rates used in Table 1.

\footnotetext{
${ }^{22}$ See Kaminsky and Schmukler (2002) for a chronology of financial liberalization.
} 
We address these issues in Tables 2 and 3, where we split the sample by income group, decade, and exchange rate regime. To keep the amount of information manageable, we proceed in the same fashion as Ghosh et al. (1999) and condense the various exchange rate regimes into the three broader categories shown in Table 1: fixed, intermediate, and floating. Table 2 presents the results for developing countries by decade and regime, while Table 3 does so for industrial countries, dividing the countries according to the World Bank classification.

Table 2 shows that the developing country subsample yields poor slope estimates for the 1970s and 1980s. In the 1970s, none of the estimates is significantly different from zero. In the 1980s, fixed regimes exhibit full transmission, with a slope estimate significantly different from zero and almost exactly equal to one - but the underlying sample consists of a single country. Intermediate and floating regimes continue to show insignificant estimates.

In contrast, the slope estimates for the 1990s are considerably larger and more precise. For intermediate and floating regimes, the point estimates are close to unity although they still exhibit relatively large standard errors. For fixed regimes we obtain a much larger slope estimate (1.81), statistically greater than one at conventional significance levels, suggesting an over-adjustment of local interest rates.

Table 3 presents the same information for industrial economies. It is important to note that, according to the IMF exchange rate regime classification, our sample does not include any industrial-country fixed regimes after the 1970s. In other words, during the 1980s and 1990s all developed countries in the sample followed either free-floating regimes or intermediate ones. Moreover, we should also note that in the 1990s the 
majority of the intermediate regime countries belong to the DM-EMU zone, and thus for this group we present estimates of the sensitivity of local interest rates to both U.S. rates and German rates.

The results in Table 3 show that the fixed regimes of the 1970s exhibit full adjustment of local to international interest rates, while intermediate and floating regimes show less-than-full adjustment in the 1970s and 1980s. The slope point estimates of the former are somewhat larger than those of the latter, although the difference between both is fairly modest.

In the 1990s, three results emerge. First, interest rates in countries with intermediate regimes are wholly unaffected by U.S. interest rates. Second, once we take account of the leading role of Germany in the DM zone, we find that the interest rates of these countries show (more than) full adjustment to German rates. Third, interest rates in countries with floating regimes also exhibit full transmission of U.S. rates. These results suggest that as developed countries became more integrated in the 1990s, their interest rates became fully sensitive to the relevant international interest rates - which in the case of the EMU zone means the German rate rather than the U.S. rate.

We next perform two robustness checks on these results. First, we add the inflation differential as an explanatory variable. As already explained, much of the variation in interest rates might reflect variation in currency and country premia, both of which could be related to inflation differentials; omission of this factor might lead to an overstatement of the role of foreign interest rates in the determination of local rates.

Second, we adopt the alternative classification of exchange rate regimes proposed by Levy Yeyati and Sturzenegger (LYS) (2000). This classification differs substantially 
from the original classification. For example, during the 1990s, only two developing countries in our sample are classified as fixed regimes according to the IMF classification, while 11 countries fall into this category according to the alternative classification. The difference narrows for intermediate regimes, with 21 and 24 being classified as such by the IMF and LYS classification, respectively. Regarding freefloating regimes, the difference widens again, with ten countries being catalogued as having such regimes according to the IMF and 19 countries according to LYS.

The fact that the LYS classification is based on actual data on exchange rate and reserve variation could help avoid some potential inaccuracies of the IMF's de jure classification. For example, monetary authorities could announce adoption of a freefloating regime but actually target tightly the exchange rate, as suggested by the fear of floating literature. Such regime would be characterized as floating in the IMF classification, and would cause our empirical procedure to understate the monetary independence allowed by floating regimes - or, equivalently, overstate the degree to which local interest rates adjust to foreign rates under floating arrangements. Likewise, a regime formally announced as pegged (and described as such by the IMF classification) might actually experience frequent realignments of the peg, which might allow the authorities considerable room for setting interest rates independently from world rates. In our empirical framework, this would cause our estimates to understate the degree of monetary transmission under pegged regimes (although to some degree this effect was captured in our additional experiments including transition dummies). Adoption of the de facto LYS classification might help overcome possible biases introduced in our estimates by the IMF de jure classification. 
Tables 4 and 5 present the results from these robustness checks for developing and industrial countries, respectively. To avoid cluttering the tables, we only report the slope coefficient estimates, omitting the estimated coefficients on the inflation differential when included in the specification.

Table 4 reports the developing-country results. The first three columns correspond to the estimates from the inflation-inclusive specification. Comparison with Table 2 reveals that the main effects from including the inflation differential are an increased precision of the intermediate-regime slope estimates in the 1970s and 1980s, and a decline in the point estimate of fixed regimes in the 1990s, which remains greater than one although not significantly so. Indeed, in the latter decade all regimes now exhibit slope estimates insignificantly different from unity, although that for fixed regimes continues to be somewhat above the rest.

The last three columns of Table 4 present the results obtained with the LYS regime classification. The slope estimates for the 1970s and 1980s are even less precise than those in Table 2, although numerically they are broadly similar. For the 1990s, the alternative classification yields somewhat lower slope estimates that the original one for fixed and intermediate regimes. The former still exhibit more-than-full interest rate adjustment (although the point estimate is not significantly greater than one), while the latter do not. Nevertheless, the slope estimate for intermediate regimes is higher in the 1990s than in the previous decades. The point estimate for floating regimes is similar, but less precise, than that obtained with the original classification, and it also suggests full interest rate adjustment. 
Table 5 presents the robustness checks for industrial countries. In this case, comparison of the first column of Table 5 with the results in Table 3 immediately reveals that inclusion of inflation in the specification is completely inconsequential for the slope point estimates. The results are virtually identical to those obtained with the basic specification.

The last three columns of Table 5 show the results obtained using the LYS regime classification. For the 1970s, the slope estimates are broadly similar to those in Table 3: fixed regimes show an estimate slightly above one, while the other regimes show much smaller values that indicate only partial interest rate adjustment. However, the relative ranking of intermediate and floating regimes is reversed relative to that in Table 3.

For the 1980s and 1990s, the alternative classification yields some fixed-regime observations, which were absent from Table 3. In the 1980s, their slope estimate is significantly smaller than one, and very similar to those obtained for the other regimes in the same decade. This suggests that in that decade all regimes behave fairly similarly they all exhibit less-than-full adjustment - what is consistent with the results for intermediate and floating regimes during the 1980s reported in Table 3.

In the 1990s the slope estimate for fixed regimes is negative and highly imprecise. Under the LYS classification, this group turns out to consist of European countries in the DM-EMU zone, so the fact that we find no response of their local interest rates to U.S. rates is quite consistent with the results in Table 3 above. For the other regimes, the estimates also show the same pattern as those in Table 3. Thus, for intermediate regimes the estimate is insignificant when the role of the DM as leading currency in Europe is ignored, and slightly above one (although not significantly so) when such role is taken 
into account. For floating regimes, the slope estimate is somewhat smaller, but also slightly above one (and again not significantly so).

To summarize this section, when heterogeneity along the income level and time dimensions is ignored, the pooled estimates by exchange rate regime seem to lend modest support to the conventional wisdom that fixed exchange rate regimes show greater sensitivity of domestic to foreign interest rates than other regimes - although in general all regimes show less-than-full transmission. Further, fixed regimes also tend to exhibit lower average interest rates, for given levels of foreign interest rates.

A closer look at the results reveals considerable differences between industrial and developing countries and across time periods. Among developing countries it is difficult to draw any clear inferences for the 1970s and 1980s, given the poor precision of most point estimates. In the former decade, intermediate regimes appear to display the highest degree of adjustment, while in the latter this role seems to correspond to pegged regimes. In the 1990s, however, all developing-country regimes display full or near-full adjustment of local to foreign interest rates - although the point estimates are generally larger for fixed regimes (for which they even exceed unity) than for the rest. Furthermore, these results are robust to the changes in specification and regime classification explored here. The only exception is the less-than-full adjustment found for intermediate regimes in the 1990s when using the alternative LYS classification.

As for industrial countries, our empirical experiments are generally more precise. Using the IMF classification we find that in the 1970s and 1980s only pegged regimes (which are present only in the former decade) exhibit full interest rate transmission, while the other regimes fall significantly short of it. In contrast, in the 1990s both intermediate 
and floating regimes show full (and, in some instances, more than full) adjustment of local interest rates to foreign rates, once account is taken of the leading role of German monetary policy in the DM zone. These conclusions hold regardless of whether inflation differentials are added to the empirical specification. Use of the alternative regime classification results in the appearance of fixed regimes in the 1980s and 1990s. In both instances they display less than full adjustment, although in the 1990s this is due to the use of the U.S. - rather than the German - interest rate as the relevant measure of "foreign interest rate" for a group of countries in the DM-EMU area. All other conclusions reached with the IMF classification remain unchanged under the alternative classification.

\section{Interest Rate Sensitivity: Dynamic Estimates}

On the whole, the pooled estimates in the previous section suggest a convergence across regimes in the 1990s towards full transmission of foreign interest rates, for both industrial and developing countries.

Given the absence of dynamics in our estimated specification, this conclusion might be viewed as implying that no exchange rate arrangement prevents eventual adjustment of local interest rates to foreign ones - i.e., no regime offers permanent monetary autonomy. It may be argued that the relevant question concerns the degree of temporary autonomy that various regimes offer to the monetary authorities - as measured by the length of time it takes for local interest rates to fully reflect changes in foreign rates. 
To explore this issue, we turn to the dynamic specification (4). As already noted, we estimate it on an individual-country basis given that a priori cross-country heterogeneity in the dynamics could be considerable, depending on country-specific factors such as financial system development and capital account regulations. Further, we focus on the 1990s, when the convergence among regimes just noted is most apparent. Finally, we focus on a few selected economies whose exchange rate regime can be categorized in a relatively straightforward manner. For developing countries, we use countries that appear classified in the same way in the IMF and LYS classifications, with the exception of Chile. (During most of the 1990s, Chile was widely known for following an exchange rate band, so we categorize it as an intermediate regime despite the fact that the LYS classification assigns Chile to the free-floating regimes.) For developed countries, we take the European countries as intermediate regimes, since they all were part of the DM-EMU area, and in addition we use a group of countries that are widely regarded as following free-floating regimes.

Tables 6 and 7 report individual-country estimates of equation (4) for developing and industrial countries, respectively. We use the Akaike information criterion to determine the length of the lag specification. ${ }^{23}$ To keep the tables manageable, we only report the estimates of the speed of adjustment $\delta$ and the long-run slope coefficient $\beta$, along with their standard errors and the p-value from the test of the null hypothesis $\beta=1$.

Table 6 presents estimation results for nine developing countries, grouped in three regime categories. Hard pegs (currency boards) consist of Argentina pre-2002 and Hong 
Kong. Intermediate regimes (including currency bands, managed floats, and similar arrangements) involve Chile, Israel, Singapore, and Thailand. Free-floating regimes comprise Mexico after the Tequila crisis, Philippines, and South Africa.

The first two rows of Table 6 report the estimates for the "hard pegs" of Argentina and Hong Kong. The estimated speeds of adjustment are numerically large and highly significant, so that the null of no long-run relation can be unambiguously rejected. The half life, calculated as $\ln (0.5) / \ln (1+\delta)$, is less than a month, around 14 days for Hong Kong and 19 days for Argentina. The point estimates of the long-run slope coefficient are close to one, even exceeding it in the case of Argentina.

The next block in Table 6 reports the results for intermediate regimes. Here the estimated speeds of adjustment are much smaller than in the hard pegs, except perhaps for Thailand. The half life ranges from more than one month in Thailand to more than seven months in Chile. In the case of Singapore, the null of no long-run relation can be rejected only for $\mathrm{I}(0)$ variables - which we regard as the most likely scenario anyway. The long-run slope estimates are statistically not different from one, although in the case of Chile the point estimate is close to three and quite imprecise. Thailand also shows a slope estimate above unity, although not significantly.

The last block in Table 6 reports the results for the three developing-country floating regimes. Their estimated speeds of adjustment, and the respective t-statistics, are lower than those found for pegged regimes - even lower than those for intermediate regimes. The half life varies between more than four months in Mexico to more than eight months in the Philippines. On the other hand, the long-run slope estimates are all

${ }^{23}$ For simplicity, we set $P=Q$ in (4). Limited experimentation removing this restriction, as well as using 
well above unity, with that of Mexico implausibly high, likely reflecting the high degree of financial turbulence over the relatively short post-Tequila sample used here. Strictly speaking, however, none of the slope coefficients is significantly different from one.

On the whole, therefore, the individual developing country estimates in Table 6 suggest full long-run adjustment of interest rates under all regimes (with some indication of over-adjustment in a majority of cases), with a faster speed of adjustment under hard pegs than under the other regimes.

Table 7 turns to the industrial countries. The top half of the table reports the estimates for five European countries in the DM zone, for which, we use the German interest rate as the benchmark measure of international rates. The speeds of adjustment range from a high of 0.47 in Portugal to a low of 0.05 in Spain, implying a half life between more than one month to more than 13 months. In the latter country the t-statistic fails to reject the null of no long-run relation, but the test is invalidated by the presence of serial correlation (as implied by the q-statistic). This might be due to the selection by the Akaike criterion of too short a dynamic specification, a problem that seems to affect also Belgium. Nevertheless, experiments imposing longer lag lengths led to similar parameter estimates. The long-run slope estimates for all these countries are above one, and significantly so in the cases of Denmark and Portugal.

The bottom half of Table 7 reports the results for six industrial-country floating regimes - three relatively small economies (Australia, New Zealand, and Canada) and three large ones (Germany, Japan, and the U.K.). The results reveal a sharp contrast between the two - more specifically, between Germany and Japan, on the one hand, and

the Schwartz criterion instead of the Akaike criterion, led to broadly similar results. 
the rest of the countries, on the other. For the smaller-country floating regimes, the speeds of adjustment are generally smaller than for the DM-zone countries. For New Zealand the estimate is also imprecise, so that formally we cannot reject the null of no long-run relation, ${ }^{24}$ although like with Spain there is some mild indication of serial correlation that might invalidate the test. The point estimates of the long-run slope are all above unity - almost significantly so in the case of Australia. The U.K. shows a long-run slope estimate smaller than unity, although not significantly so, and its speed of adjustment is somewhat above those of the smaller economies.

For Germany and Japan, the situation is radically different. The speed of adjustment estimates are very close to, and insignificantly different from, zero. Moreover, the estimates are quite precise. Imposing other lag specifications instead of the one selected by the Akaike criterion in Table 7 does not alter this result. Thus, for these two countries we cannot reject the null of no long-run relation between domestic and foreign interest rates at any reasonable confidence level. Since the estimated equations show no symptom of serial correlation, the result is not due to dynamic misspecification. Absent a long-run relation, the long-run slope estimates are meaningless and thus we omit them from the table.

Like with the pooled estimates, we examined the sensitivity of the results reported in this section to inclusion of the inflation differential in the long-run equilibrium

\footnotetext{
${ }^{24}$ Inspection of the critical values of Pesaran, Shin, and Smith (2001) shows that we can reject the null at the 10 percent level if the variables are $\mathrm{I}(0)$.
} 
condition, and to exclusion of the inflation differential from both the long run and the dynamics. The results changed only very marginally. ${ }^{25}$

To summarize this section, the individual-country dynamic estimates for the 1990s show that only two major industrial economies (Germany and Japan) with floating regimes vis-à-vis the U.S. fail to exhibit adjustment of their interest rates to the U.S. interest rate. In this sense, only these two economies display clear evidence of monetary independence over the sample period.

With this exception, the country-specific estimates coincide with the pooled estimates in suggesting that over the 1990s all exchange regimes display full adjustment of domestic to international interest rates in the long run. Indeed, for some floatingregime developing countries and smaller industrial economies we find evidence of overadjustment - i.e., local rates move more than one-for-one with foreign rates.

The dynamic estimates also provide an idea of how long the long run is under each exchange rate regime - i.e., how long it takes for local interest rates to adjust to international rates. For developing-country hard pegs, the long run seems in fact quite short - these regimes exhibit the fastest adjustment of local interest rates among all regimes examined. At the other extreme, floating regimes seem to allow the longest transition period, both among developing and industrial countries. In this sense, our results seem to accord with the conventional wisdom that floating regimes provide increased room for temporary monetary independence.

\footnotetext{
${ }^{25}$ Specifically, the main consequence of including inflation in the long run relation is to lower Mexico's long-run slope estimate from 24 to 4, and Chile's from 2.9 to 1.5. Excluding inflation from both the dynamics and the long-run equilibrium yields results very similar to those reported in the text.
} 


\section{Conclusions}

In this paper we have tested whether the transmission of international interest rate changes to local rates is affected by the exchange rate regime. This is an important question in the context of the debate on the choice of currency regime, in which the issue of monetary independence has played a central role. Proponents of free-floating arrangements have argued that countries adopting floating regimes would be able to pursue their own monetary policy goals, while advocates of hard pegs have questioned the feasibility of such a strategy in a world of high international capital mobility.

The paper has taken a first step towards assessing empirically the relative merits of these two views, by reviewing the empirical regularities on international interest rate linkages for a large sample of industrial and developing countries. The approach taken here extends and generalizes earlier studies that have focused on a small group of countries over brief time periods. Specifically, the paper has examined the evidence from industrial and developing countries over the last three decades, using both pooled and single-country empirical estimates. The objective is to establish the main stylized facts that will need to be addressed in the debate on monetary independence and the choice of currency regime. To do this, we have employed simple reduced-form specifications relating domestic to world interest rates. In spite of their simplicity, the empirical models capture a considerable proportion of the variance in local interest rates, both across countries and over time.

The main results of the paper can be summarized in three points. First, over the last decade all exchange rate regimes exhibit high sensitivity of local interest rates to international ones. Indeed, in the 1990s we find virtually no instances of less-than-full 
long-run transmission, regardless of exchange rate regime. This result emerges from both the country-specific estimates and the pooled estimates, and for industrial and developing countries alike. Interestingly, during the 1990s, interest rates in European countries of the DM-EMU zone have become virtually insensitive to U.S. interest rates - but fully sensitive to German interest rates. Thus, European countries have shifted from the U.S. monetary area to the DM-EMU monetary, and the observed decline in the responsiveness of their interest rates to U.S. interest rates does not signify any increase in their degree of monetary independence.

Second, our single-country dynamic estimates show that floating regimes do entail increased monetary independence in the specific sense that the speed of adjustment of domestic interest rates towards the long-run, one-for-one relation with international rates is generally lower under floating regimes than under other regimes. Hence floating regimes appear to offer at least a degree of temporary monetary independence.

Third, the only exception to these general results is provided by two large industrial countries (Germany and Japan), for which we find no evidence in the data of a long-run relation between local and international (U.S.) interest rates. Hence these countries appear to be the only ones that can, and choose, to benefit from independent monetary policy in the 1990s.

On the whole, these results are robust to changes in empirical specification and, in the case of the pooled estimates, to the use of alternative systems of classification of exchange regimes.

It is important to note one caveat of our analysis. Our assessment of monetary independence is based on the observed degree of comovement of local and foreign 
interest rates. Thus, our approach could understate the actual degree of monetary independence offered by non-pegged regimes if their monetary authorities opt for not making use of their monetary autonomy - be it due to fear of floating or because the cycle at home and abroad happen to require very similar monetary policy stances.

To conclude, the empirical regularities identified in the paper leave many questions open for future research. We shall mention three. The first one concerns the interpretation of our finding of full transmission in the 1990s, in fixed and flexible regimes alike, except for large industrial economies. Does this mean that floating-regime countries are not able to pursue their independent monetary policy, or rather that they choose not to float, perhaps due to fear of floating?

More generally, we have not explored the channels through which international interest rates are transmitted to domestic rates - i.e., the relative roles of business cycle synchronization, common shocks, and policy decisions. Nor have we examined the impact of international rates on the country premium and the currency premium of local interest rates. These questions are left for future research. 


\section{Appendix: Exchange Rate Regime Classification}

The starting point is the IMF's quarterly database on exchange rate regimes, which encompasses a total of 10 categories, based on officially reported exchange arrangements for the period 1975-1996.

We transform the IMF database to a monthly basis, complementing the original source with information contained in Cottarelli and Giannini (1997). Finally, the classification is extended until March 1999, using information from IMF reports and publications, including the Exchange Rate Arrangements and Restrictions and the International Finance Statistics, 1998 and 1999. For the countries used in the individualcountry estimates, we extend the classification until December 1999. In addition to the original classification, we construct new categories to account for the specific currency to which some fixed regimes are pegged.

For most experiments in the paper, we condense the ten categories in the original source into three broader exchange rate regimes: fixed (pegs), intermediate (limited flexibility, crawls, bands, managed floating), and flexible (free-floating). Specifically, pegged regimes include: peg to the U.S. dollar, peg to the French franc, peg to other currencies (comprising Indian rupee, South African rand, British pound, and Deutsche mark), peg to SDR (IMF basket), and basket pegs (including the so-called Bretton Woods basket peg). Intermediate regimes include: limited flexibility with respect to a basket, limited flexibility with respect to a single currency, limited flexibility with respect to a cooperative arrangement (including the European Monetary System), managed floating, crawling pegs, and crawling bands. The full details are given in the Appendix Table. 


\section{References}

Baltagi, B., 2000, Nonstationary Panels, Panel Cointegration, and Dynamic Panels, Elsevier Science.

Banerjee, A., J. Dolado, J. Galbraith, and D. Hendry, 1993, Co-integration, Error Correction, and the Econometric Analysis of Nonstationary Data, Oxford University Press.

Bardsen, G., 1989, "Estimation of Long-Run Coefficients in Error-Correction Models," Oxford Bulletin of Economics and Statistics, 51, p. 345-350.

Borensztein, Eduardo, Jeromin Zettelmeyer, Thomas Philippon, 2001, "Monetary Independence in Emerging Markets: Does the Exchange Rate Make a Difference," IMF Working Paper WP/01/1.

Boswijk, P., 1995, "Efficient Inference on Cointegration Parameters in Structural Error Correction Models," Journal of Econometrics, 69, 133-158.

Calvo, Guillermo and Carmen Reinhart, 2001, "Fixing for Your Life," Brookings Trade Forum 2000, pp. 1-39.

Calvo, Guillermo and Carmen Reinhart, 2002, "Fear of Floating," Quarterly Journal of Economics, 117:2.

Cochrane, John, 1991, "Comment on Campbell and Perron," in Olivier Blanchard and Stanley Fischer, NBER Macroeconomics Annual, pp. 201-210.

Cottarelli, Carlo, and C. Giannini, 1997, "Credibility Without Rules," IMF Occasional Paper No. 154, December.

Edwards, Sebastian and Miguel Savastano, 1999, "Exchange Rates in Emerging Economies: What Do We Know? What Do We Need to Know?" NBER Working Paper No. 7228, July.

Frankel, Jeffrey, 1999, "No Single Exchange Rate Regime is Right for All Countries or at All Times," Graham Lecture, Princeton University. Essays in International Finance No. 215, Princeton University Press: Princeton, August 1999.

Frankel, Jeffrey, Sergio Schmukler, and Luis Servén, 2001, "Verifiability and the Vanishing Intermediate Exchange Rate Regime," Journal of Development Economics, 66:2, pp. 351-386.

Ghosh, A., A. Gulde, J. Ostry, and H. Wolf, 1996, "Does The Nominal Exchange Rate Regime Matter?” IMF Economic Issues No. 2, NBER Working Paper No. 5874 
Hausmann, Ricardo, Michael Gavin, Carmen Pages-Serra, and Ernesto Stein, 1999, "Financial Turmoil and the Choice of Exchange Rate Regime," mimeo, InterAmerican Development Bank.

Hausmann, Ricardo, Ugo Panizza, and Ernesto Stein, 2001, "Why Do Countries Float the Way They Float?” Journal of Development Economics, 66:2, pp. 387-414.

Holman, Jill and Felix Rioja, 2001, "International Transmission of Anticipated Inflation under Alternative Exchange-Rate Regimes," Journal of International Money and Finance, 20:4, pp. 497-519.

Kaminsky, Graciela and Sergio Schmukler, 2001, "Short-Lived or Long-Lasting? A New Look at the Effects of Capital Controls," Brookings Trade Forum 2000, pp. 125:178.

Kaminsky, Graciela and Sergio Schmukler, 2002, "Short-Run Pain, Long-Run Gain: The Effects of Financial Liberalization," mimeo, GWU and World Bank.

Levy Yeyati, Eduardo and Federico Sturzenegger, 2000, "Classifying Exchange Rate Regimes: Deeds vs. Words," mimeo, Universidad T. Di Tella.

Pesaran, M. Hashem, 1997, "The Role of Economic Theory in Modeling the Long Run," Economic Journal, 107, 178-91.

Pesaran, M. Hashem and Yongcheol Shin, 1999, "An Autoregressive Distributed Lag Modelling Approach to Cointegration Analysis," in Econometrics and Economic Theory in the 20th Century: The Ragnar Frisch Centennial Symposium, chapter 11, (ed.) S. Strom, Cambridge University Press, Cambridge.

Pesaran, M. Hashem, Yongcheol Shin, and Richard Smith, 2001, "Bounds Testing Approaches to the Analysis of Level Relationships," Journal of Applied Econometrics, 16, 289-326.

Pesaran, M. Hashem, and Ron Smith, 1995, "Estimating Long-Run Relationships from Dynamic Heterogeneous Panels," Journal of Econometrics, 68, 79-113. 


\section{Table 1}

\section{Local Interest Rate Responsiveness to U.S. T-bill Rate by Exchange Rate Regime}

The table reports the constant and slope coefficients of the local interest rate (money market) on the U.S. T-bill rate. The models are calculated by exchange rate regime. All regressions contain country fixed effects, which are not reported in the table to save space. Data are from industrialized and developing countries in the 1970s, 1980s, and 1990s. Newey-West standard errors are in parenthesis. $* *$ and

* mean that the estimate is statistically different from zero at the 5 percent and 10 percent significance level respectively.

\begin{tabular}{|c|c|c|c|c|c|}
\hline & Constant & $\begin{array}{l}\text { International } \\
\text { interest rate }\end{array}$ & $\begin{array}{c}\text { Test } \\
\text { slope }=1 \\
\text { (p-value) }\end{array}$ & R-squared & $\begin{array}{c}\text { Number of } \\
\text { countries } \\
\text { (observations) }\end{array}$ \\
\hline Fixed regimes & $\begin{array}{l}0.05 \text { ** } \\
(0.01)\end{array}$ & $\begin{array}{l}0.62 \text { ** } \\
(0.26)\end{array}$ & 0.14 & 0.66 & $\begin{array}{c}13 \\
(517)\end{array}$ \\
\hline pegged to U.S. dollar & $\begin{array}{l}0.08 \text { ** } \\
(0.02)\end{array}$ & $\begin{array}{r}0.58 \\
(0.37)\end{array}$ & 0.26 & 0.61 & $\begin{array}{c}7 \\
(323)\end{array}$ \\
\hline pegged to other currencies & $\begin{array}{r}0.02 \\
(0.00)\end{array}$ & $\begin{array}{r}0.64 \text { ** } \\
(0.28)\end{array}$ & 0.20 & 0.71 & $\begin{array}{c}8 \\
(194)\end{array}$ \\
\hline Intermediate regimes & $\begin{array}{l}0.10 \text { ** } \\
(0.00)\end{array}$ & $\begin{array}{l}0.53 * * \\
(0.09)\end{array}$ & 0.00 & 0.74 & $\begin{array}{c}38 \\
(6,109)\end{array}$ \\
\hline band & $\begin{array}{l}0.05^{* *} \\
(0.00)\end{array}$ & $\begin{array}{r}0.60 \text { ** } \\
(0.08)\end{array}$ & 0.00 & 0.52 & $\begin{array}{c}30 \\
(4,098)\end{array}$ \\
\hline managed floating & $\begin{array}{r}0.11 \text { ** } \\
(0.02)\end{array}$ & $\begin{array}{r}0.17 \\
(0.32)\end{array}$ & 0.01 & 0.72 & $\begin{array}{c}27 \\
(2,011)\end{array}$ \\
\hline Free-floating regimes & $\begin{array}{l}0.40 \text { ** } \\
(0.02)\end{array}$ & $\begin{array}{l}0.53 \text { ** } \\
(0.20)\end{array}$ & 0.02 & 0.82 & $\begin{array}{c}26 \\
(2,713)\end{array}$ \\
\hline
\end{tabular}




\section{Table 2}

\section{Local Interest Rate Responsiveness to U.S. T-bill Rate Developing Countries by Decade}

The table reports the slope coefficient of the local interest rate (money market) on the U.S. T-bill rate. The models are calculated by exchange rate regime. All regressions contain country fixed effects, which are not reported in the table to save space. Newey-West standard errors are in parenthesis. ** and * mean that the estimate is statistically different from zero at the 5 percent and 10 percent significance level respectively.

\begin{tabular}{|c|c|c|c|c|}
\hline & $\begin{array}{l}\text { International } \\
\text { interest rate }\end{array}$ & $\begin{array}{c}\text { Test } \\
\text { slope }=1 \\
\text { (p-value) }\end{array}$ & R-squared & $\begin{array}{c}\text { Number of } \\
\text { countries } \\
\text { (observations) }\end{array}$ \\
\hline \multicolumn{5}{|l|}{ 1970s: } \\
\hline Fixed regimes & $\begin{array}{r}0.05 \\
(0.11)\end{array}$ & 0.00 & 0.94 & $\begin{array}{c}4 \\
(191)\end{array}$ \\
\hline Intermediate regimes & $\begin{array}{r}0.47 \\
(0.31)\end{array}$ & 0.09 & 0.96 & $\begin{array}{c}5 \\
(177)\end{array}$ \\
\hline Free-floating regimes & $\begin{array}{l}-0.52 \\
(0.63)\end{array}$ & 0.02 & 0.94 & $\begin{array}{c}2 \\
(42)\end{array}$ \\
\hline \multicolumn{5}{|l|}{ 1980s: } \\
\hline Fixed regimes & $\begin{array}{l}0.99 * * \\
(0.46)\end{array}$ & 0.98 & 0.15 & $\begin{array}{c}1 \\
(29)\end{array}$ \\
\hline Intermediate regimes & $\begin{array}{r}0.08 \\
(0.56)\end{array}$ & 0.10 & 0.73 & $\begin{array}{c}13 \\
(1,091)\end{array}$ \\
\hline Free-floating regimes & $\begin{array}{l}-0.12 \\
(0.46)\end{array}$ & 0.01 & 0.90 & $\begin{array}{c}4 \\
(294)\end{array}$ \\
\hline \multicolumn{5}{|l|}{ 1990s: } \\
\hline Fixed regimes & $\begin{array}{l}1.81 * * \\
(0.36)\end{array}$ & 0.02 & 0.09 & $\begin{array}{c}2 \\
(164)\end{array}$ \\
\hline Intermediate regimes & $\begin{array}{r}0.81 * \\
(0.44)\end{array}$ & 0.67 & 0.78 & $\begin{array}{c}22 \\
(1,665)\end{array}$ \\
\hline Free-floating regimes & $\begin{array}{r}0.91 * \\
(0.47)\end{array}$ & 0.84 & 0.54 & $\begin{array}{c}10 \\
(575)\end{array}$ \\
\hline
\end{tabular}


Table 3

\section{Local Interest Rate Responsiveness to International Interest Rates Industrialized Countries by Decade}

The table reports the slope coefficient of the local interest rate (money market) on the U.S. and German T-bill rate. The models are calculated by exchange rate regime. All regressions contain country fixed effects, which are not reported in the table to save space. Newey-West standard errors are in parenthesis. ** and * mean that the estimate is statistically different from zero at the 5 percent and 10 percent significance level respectively.

\begin{tabular}{|c|c|c|c|c|}
\hline & $\begin{array}{l}\text { International } \\
\text { interest rate }\end{array}$ & $\begin{array}{c}\text { Test } \\
\text { slope }=1 \\
\text { (p-value) }\end{array}$ & R-squared & $\begin{array}{c}\text { Number of } \\
\text { countries } \\
\text { (observations) }\end{array}$ \\
\hline \multicolumn{5}{|l|}{ 1970s: } \\
\hline $\begin{array}{l}\text { Fixed regimes } \\
\text { (U.S. T-bill rate) }\end{array}$ & $\begin{array}{l}1.03 * * \\
(0.19)\end{array}$ & 0.87 & 0.79 & $\begin{array}{c}6 \\
(133)\end{array}$ \\
\hline $\begin{array}{l}\text { Intermediate regimes } \\
\text { (U.S. T-bill rate) }\end{array}$ & $\begin{array}{l}0.58 * * \\
(0.13)\end{array}$ & 0.00 & 0.33 & $\begin{array}{c}11 \\
(845)\end{array}$ \\
\hline $\begin{array}{l}\text { Free-floating regimes } \\
\text { (U.S. T-bill rate) }\end{array}$ & $\begin{array}{r}0.43 \\
(0.28)\end{array}$ & 0.04 & 0.55 & $\begin{array}{c}7 \\
(382)\end{array}$ \\
\hline \multicolumn{5}{|l|}{ 1980s: } \\
\hline $\begin{array}{l}\text { Fixed regimes } \\
\text { (U.S. T-bill rate) }\end{array}$ & .. & .. & .. & .. \\
\hline $\begin{array}{l}\text { Intermediate regimes } \\
\text { (U.S. T-bill rate) }\end{array}$ & $\begin{array}{l}0.49 * * \\
(0.10)\end{array}$ & 0.00 & 0.71 & $\begin{array}{c}12 \\
(1,314)\end{array}$ \\
\hline $\begin{array}{l}\text { Free-floating regimes } \\
\text { (U.S. T-bill rate) }\end{array}$ & $\begin{array}{r}0.36 * \\
(0.19)\end{array}$ & 0.00 & 0.78 & $\begin{array}{c}7 \\
(616)\end{array}$ \\
\hline \multicolumn{5}{|l|}{ 1990s: } \\
\hline $\begin{array}{l}\text { Fixed regimes } \\
\text { (U.S. T-bill rate) }\end{array}$ & .. & .. & .. & .. \\
\hline $\begin{array}{l}\text { Intermediate regimes } \\
\text { (U.S. T-bill rate) }\end{array}$ & $\begin{array}{r}0.00 \\
(0.15)\end{array}$ & 0.00 & 0.24 & $\begin{array}{c}13 \\
(1,068)\end{array}$ \\
\hline $\begin{array}{l}\text { Intermediate Regimes } \\
\text { (German T-bill rate) }\end{array}$ & $\begin{array}{l}1.26^{* * *} \\
(0.09)\end{array}$ & 0.00 & 0.58 & $\begin{array}{c}13 \\
(1,068)\end{array}$ \\
\hline $\begin{array}{l}\text { Free-floating regimes } \\
\text { (U.S. T-bill rate) }\end{array}$ & $\begin{array}{l}0.94 * * \\
(0.29)\end{array}$ & 0.84 & 0.48 & $\begin{array}{c}10 \\
(804)\end{array}$ \\
\hline
\end{tabular}


Table 4

Alternative Specifications of Local Interest Rate Responsiveness to U.S. T-bill Rate Developing Countries by Decade

This table presents two variations of the regressions reported in Table 2. The first variation includes the inflation differential between each country and the U.S. as a regressor; the second one uses the Levy Yeyati and Sturzenegger (2000) classification of exchange rate regimes. The table reports only the coefficients of the local interest rate (money market) on the U.S. T-bill rate to save space. The models are calculated by exchange rate regime. All regressions contain country fixed effects, which are not reported in the table to save space. Newey-West standard errors are in parenthesis. $* *$ and $*$ mean that the estimate is statistically different from zero at the 5 percent and 10 percent significance level respectively.

\begin{tabular}{|c|c|c|c|c|c|c|c|c|c|}
\hline & \multicolumn{4}{|c|}{ With inflation rate } & \multicolumn{5}{|c|}{ Alternative regime classification } \\
\hline & $\begin{array}{l}\text { International } \\
\text { interest rate }\end{array}$ & $\begin{array}{c}\text { Test } \\
\text { slope }=1 \\
\text { (p-value) }\end{array}$ & R-squared & $\begin{array}{c}\text { Number of } \\
\text { countries } \\
\text { (observations) }\end{array}$ & $\begin{array}{l}\text { International } \\
\text { interest rate }\end{array}$ & & $\begin{array}{c}\text { Test } \\
\text { slope = } 1 \\
\text { (p-value) }\end{array}$ & R-squared & $\begin{array}{c}\text { Number of } \\
\text { countries } \\
\text { (observations) }\end{array}$ \\
\hline \multicolumn{10}{|l|}{ 1970s: } \\
\hline Fixed regimes & $\begin{array}{r}0.05 \\
(0.10)\end{array}$ & 0.00 & 0.94 & $\begin{array}{c}4 \\
(191)\end{array}$ & $\begin{array}{r}0.27 \\
(0.25)\end{array}$ & & 0.00 & 0.93 & $\begin{array}{c}4 \\
(214)\end{array}$ \\
\hline Intermediate regimes & $\begin{array}{r}0.51 \\
(0.27)\end{array}$ & 0.07 & 0.96 & $\begin{array}{c}5 \\
(177)\end{array}$ & $\begin{array}{r}0.45 \\
(0.39)\end{array}$ & & 0.15 & 0.96 & $\begin{array}{c}3 \\
(130)\end{array}$ \\
\hline Free-floating regimes & $\begin{array}{r}-0.48 \\
(0.71)\end{array}$ & 0.04 & 0.94 & $\begin{array}{c}2 \\
(42)\end{array}$ & $\begin{array}{r}-0.49 \\
(0.44)\end{array}$ & & 0.00 & 0.95 & $\begin{array}{c}3 \\
(66)\end{array}$ \\
\hline \multicolumn{10}{|l|}{ 1980s: } \\
\hline Fixed regimes & $\begin{array}{l}0.87 * \\
(0.49)\end{array}$ & 0.79 & 0.17 & $\begin{array}{c}1 \\
(29)\end{array}$ & $\begin{array}{r}0.70 \\
(0.62)\end{array}$ & & 0.62 & 0.93 & $\begin{array}{c}8 \\
(201)\end{array}$ \\
\hline Intermediate regimes & $\begin{array}{l}0.42 * * \\
(0.18)\end{array}$ & 0.00 & 0.87 & $\begin{array}{c}13 \\
(1,091)\end{array}$ & $\begin{array}{r}0.34 \\
(0.72)\end{array}$ & & 0.36 & 0.82 & $\begin{array}{c}14 \\
(853)\end{array}$ \\
\hline Free-floating regimes & $\begin{array}{r}-0.01 \\
(0.45)\end{array}$ & 0.03 & 0.90 & $\begin{array}{c}4 \\
(294)\end{array}$ & $\begin{array}{r}-0.24 \\
(0.57)\end{array}$ & & 0.03 & 0.84 & $\begin{array}{c}10 \\
(360)\end{array}$ \\
\hline \multicolumn{10}{|l|}{ 1990s: } \\
\hline Fixed regimes & $\begin{array}{l}1.09 * * \\
(0.25)\end{array}$ & 0.72 & 0.64 & $\begin{array}{c}2 \\
(164)\end{array}$ & $\begin{array}{r}1.13 \\
(0.35)\end{array}$ & ** & 0.71 & 0.89 & $\begin{array}{c}11 \\
(352)\end{array}$ \\
\hline Intermediate regimes & $\begin{array}{l}0.76 \text { ** } \\
(0.37)\end{array}$ & 0.53 & 0.82 & $\begin{array}{c}22 \\
(1,665)\end{array}$ & $\begin{array}{r}0.52 \\
(0.22)\end{array}$ & $* *$ & 0.03 & 0.72 & $\begin{array}{c}24 \\
(1,237)\end{array}$ \\
\hline Free-floating regimes & $\begin{array}{r}0.82 \\
(0.45)\end{array}$ & 0.69 & 0.55 & $\begin{array}{c}10 \\
(575)\end{array}$ & $\begin{array}{r}0.97 \\
(0.79)\end{array}$ & & 0.97 & 0.84 & $\begin{array}{c}19 \\
(764)\end{array}$ \\
\hline
\end{tabular}


Table 5

Alternative Specifications of Local Interest Rate Responsiveness to International Interest Rates Industrialized Countries by Decade

This table presents two variations of the regressions reported in Table 3. The first variation includes the inflation differential between each country and the U.S. or Germany as a regressor; the second one uses the Levy Yeyati and Sturzenegger (2000) classification of exchange rate regimes. The table reports only the coefficients of the local interest rate (money market) on the U.S. and German T-bill rate to save space. The models are calculated by exchange rate regime. All regressions contain country fixed effects, which are not reported in the table to save space. Newey-West standard errors are in parenthesis. $* *$ and $*$ mean that the estimate is statistically different from zero at the 5 percent and 10 percent significance level respectively.

\begin{tabular}{|c|c|c|c|c|c|c|c|c|}
\hline & \multicolumn{4}{|c|}{ With inflation rate } & \multicolumn{4}{|c|}{ Alternative regime classification } \\
\hline & $\begin{array}{l}\text { International } \\
\text { interest rate }\end{array}$ & $\begin{array}{c}\text { Test } \\
\text { slope }=1 \\
\text { (p-value) }\end{array}$ & R-squared & $\begin{array}{c}\text { Number of } \\
\text { countries } \\
\text { (observations) }\end{array}$ & $\begin{array}{l}\text { International } \\
\text { interest rate }\end{array}$ & $\begin{array}{c}\text { Test } \\
\text { slope }=1 \\
\text { (p-value) }\end{array}$ & R-squared & $\begin{array}{c}\text { Number of } \\
\text { countries } \\
\text { (observations) }\end{array}$ \\
\hline \multicolumn{9}{|l|}{ 1970s: } \\
\hline $\begin{array}{l}\text { Fixed regimes } \\
\text { (U.S. T-bill rate) }\end{array}$ & $\begin{array}{l}1.03 * * \\
(0.19)\end{array}$ & 0.87 & 0.79 & $\begin{array}{c}6 \\
(133)\end{array}$ & $\begin{array}{l}1.07 * * \\
(0.16)\end{array}$ & 0.64 & 0.51 & $\begin{array}{c}5 \\
(148)\end{array}$ \\
\hline $\begin{array}{l}\text { Intermediate regimes } \\
\text { (U.S. T-bill rate) }\end{array}$ & $\begin{array}{l}0.60 * * \\
(0.13)\end{array}$ & 0.00 & 0.33 & $\begin{array}{c}11 \\
(845)\end{array}$ & $\begin{array}{l}0.32 * * \\
(0.10)\end{array}$ & 0.00 & 0.39 & $\begin{array}{c}12 \\
(693)\end{array}$ \\
\hline $\begin{array}{l}\text { Free-floating regimes } \\
\text { (U.S. T-bill rate) }\end{array}$ & $\begin{array}{l}0.53 * \\
(0.27)\end{array}$ & 0.08 & 0.57 & $\begin{array}{c}7 \\
(382)\end{array}$ & $\begin{array}{l}0.57 * * \\
(0.21)\end{array}$ & 0.04 & 0.45 & $\begin{array}{c}11 \\
(519)\end{array}$ \\
\hline \multicolumn{9}{|l|}{ 1980s: } \\
\hline $\begin{array}{l}\text { Fixed regimes } \\
\text { (U.S. T-bill rate) }\end{array}$ &.. & .. &.. &.. & $\begin{array}{l}0.51 * * \\
(0.16)\end{array}$ & 0.00 & 0.73 & $\begin{array}{c}8 \\
(322)\end{array}$ \\
\hline $\begin{array}{l}\text { Intermediate regimes } \\
\text { (U.S. T-bill rate) }\end{array}$ & $\begin{array}{l}0.49 * * \\
(0.10)\end{array}$ & 0.00 & 0.72 & $\begin{array}{c}12 \\
(1,314)\end{array}$ & $\begin{array}{l}0.44 * * \\
(0.14)\end{array}$ & 0.00 & 0.79 & $\begin{array}{c}14 \\
(986)\end{array}$ \\
\hline $\begin{array}{l}\text { Free-floating regimes } \\
\text { (U.S. T-bill rate) }\end{array}$ & $\begin{array}{l}0.38 * * \\
(0.19)\end{array}$ & 0.00 & 0.79 & $\begin{array}{c}7 \\
(616)\end{array}$ & $\begin{array}{l}0.49 * * \\
(0.12)\end{array}$ & 0.00 & 0.69 & $\begin{array}{c}9 \\
(622)\end{array}$ \\
\hline \multicolumn{9}{|l|}{ 1990s: } \\
\hline $\begin{array}{l}\text { Fixed regimes } \\
\text { (U.S. T-bill rate) }\end{array}$ &.. &.$\cdot$ & .. &.. & $\begin{array}{r}-0.71 \\
(0.38)\end{array}$ & 0.00 & 0.15 & $\begin{array}{c}9 \\
(562)\end{array}$ \\
\hline $\begin{array}{l}\text { Intermediate regimes } \\
\text { (U.S. T-bill rate) }\end{array}$ & $\begin{array}{r}0.02 \\
(0.16)\end{array}$ & 0.00 & 0.25 & $\begin{array}{c}13 \\
(1,068)\end{array}$ & $\begin{array}{r}0.40 \\
(0.29)\end{array}$ & 0.04 & 0.35 & $\begin{array}{c}12 \\
(667)\end{array}$ \\
\hline $\begin{array}{l}\text { Intermediate regimes } \\
\text { (German T-bill rate) }\end{array}$ & $\begin{array}{l}1.26 * * \\
(0.09)\end{array}$ & 0.00 & 0.58 & $\begin{array}{c}13 \\
(1,068)\end{array}$ & $\begin{array}{l}1.16 * * \\
(0.09)\end{array}$ & 0.09 & 0.70 & $\begin{array}{c}12 \\
(667)\end{array}$ \\
\hline $\begin{array}{l}\text { Free-floating regimes } \\
\text { (U.S. T-bill rate) }\end{array}$ & $\begin{array}{l}0.92 * * \\
(0.29)\end{array}$ & 0.79 & 0.48 & $\begin{array}{c}10 \\
(804)\end{array}$ & $\begin{array}{l}1.05 * * \\
(0.29)\end{array}$ & 0.86 & 0.61 & $\begin{array}{c}11 \\
(643)\end{array}$ \\
\hline
\end{tabular}




\section{Table 6}

\section{Local Interest Rate Responsiveness to U.S. T-bill Rate Developing Countries}

The table reports the coefficients and test of error correction models by country, which include the inflation rate in the dynamics. The main text describes the equation being estimated. The table reports the adjustment coefficient and the coefficient on the international interest rate from the long-run relation. Newey-West standard errors are in parenthesis. $* *$ and $*$ mean that the estimate is statistically different from zero at the 5 percent and 10 percent significance level respectively. \#\# means that the t-statistic rejects the null of no long-run relation at the 5 percent level regardless of the order of integration of the variables; \# means that the rejection applies only to I(0) variables (see Pesaran, Shin, and Smith 2001).

\begin{tabular}{|c|c|c|c|c|c|c|c|c|}
\hline & Sample & $\begin{array}{c}\text { Number of } \\
\text { lags }\end{array}$ & $\begin{array}{c}\text { Adjustment } \\
\text { coefficient }\end{array}$ & $\begin{array}{c}\text { International } \\
\text { interest rate } \\
\text { (long-run relation) } \\
\end{array}$ & $\begin{array}{c}\text { Test } \\
\text { slope }=1 \\
\text { (p-value) } \\
\end{array}$ & R-squared & $\begin{array}{c}\text { Q-statistic at } \\
\text { lag } 3 \\
\text { (p-value) } \\
\end{array}$ & $\begin{array}{l}\text { Number of } \\
\text { observations }\end{array}$ \\
\hline \multicolumn{9}{|c|}{ Fixed regimes: } \\
\hline Argentina & $1 / 91-12 / 99$ & 2 & $\begin{array}{r}0.66 \text { ** } \\
(0.06) \text { \#\# }\end{array}$ & $\begin{array}{l}1.28 * * \\
(0.34)\end{array}$ & 0.41 & 0.73 & 0.14 & 106 \\
\hline Hong Kong & $1 / 94-12 / 99$ & 0 & $\begin{array}{r}0.78 * * \\
(0.12) \# \#\end{array}$ & $\begin{array}{l}0.91 * * \\
(0.43)\end{array}$ & 0.84 & 0.41 & 0.78 & 72 \\
\hline \multicolumn{9}{|c|}{ Intermediate regimes: } \\
\hline Chile & $1 / 90-8 / 99$ & 1 & $\begin{array}{r}0.09 * * \\
(0.03) \# \#\end{array}$ & $\begin{array}{r}2.86 \\
(1.99)\end{array}$ & 0.35 & 0.86 & 0.26 & 115 \\
\hline Israel & $1 / 90-12 / 99$ & 2 & $\begin{array}{r}0.15 * * \\
(0.04) \text { \#\# }\end{array}$ & $\begin{array}{l}0.83 * * \\
(0.29)\end{array}$ & 0.56 & 0.37 & 0.59 & 118 \\
\hline Singapore & $1 / 90-12 / 99$ & 3 & $\begin{array}{c}0.12 * * \\
(0.05) \#\end{array}$ & $\begin{array}{l}0.99 * * \\
(0.43)\end{array}$ & 0.97 & 0.28 & 0.93 & 117 \\
\hline Thailand & $1 / 90-3 / 97$ & 0 & $\begin{array}{r}0.48 * * \\
(0.09) \text { \#\# }\end{array}$ & $\begin{array}{l}1.40 * * \\
(0.30)\end{array}$ & 0.20 & 0.25 & 0.89 & 87 \\
\hline \multicolumn{9}{|c|}{ Free-floating regimes: } \\
\hline Mexico & $12 / 94-12 / 99$ & 0 & $\begin{array}{l}0.15 * * \\
(0.06) \#\end{array}$ & $\begin{array}{l}24.50 * * \\
(11.94)\end{array}$ & 0.05 & 0.42 & 0.71 & 61 \\
\hline Philippines & $1 / 90-12 / 99$ & 2 & $\begin{array}{c}0.08 * * \\
(0.03) \#\end{array}$ & $\begin{array}{l}2.16 * * \\
(0.95)\end{array}$ & 0.23 & 0.16 & 0.84 & 118 \\
\hline South Africa & 1/90--12/99 & 1 & $\begin{array}{c}0.09 * * \\
(0.04) \#\end{array}$ & $\begin{array}{l}1.75 \text { ** } \\
(0.58)\end{array}$ & 0.20 & 0.15 & 0.96 & 119 \\
\hline
\end{tabular}




\section{Table 7}

\section{Local Interest Rate Responsiveness to International Interest Rates Industrialized Countries}

The table reports the coefficients and test of error correction models by country, which include the inflation rate in the dynamics. The main text describes the equation being estimated. The table reports the adjustment coefficient and the coefficient on the international interest rate from the long-run relation. Newey-West standard errors are in parenthesis. ${ }^{* *}$ and $*$ mean that the estimate is statistically different from zero at the 5 percent and 10 percent significance level respectively. \#\# means that the t-statistic rejects the null of no long-run relation at the 5 percent level regardless of the order of integration of the variables; \# means that the rejection applies only to I(0) variables (see Pesaran, Shin, and Smith 2001). N/A means not applicable.

\begin{tabular}{|c|c|c|c|c|c|c|c|c|}
\hline & Sample & $\begin{array}{c}\text { Number of } \\
\text { lags }\end{array}$ & $\begin{array}{l}\text { Adjustment } \\
\text { coefficient }\end{array}$ & $\begin{array}{c}\text { International } \\
\text { interest rate } \\
\text { (long-run relation) }\end{array}$ & $\begin{array}{c}\text { Test } \\
\text { slope }=1 \\
\text { (p-value) }\end{array}$ & R-squared & $\begin{array}{c}\text { Q-statistic at } \\
\text { lag } 3 \\
\text { (p-value) }\end{array}$ & $\begin{array}{c}\text { Number of } \\
\text { observations }\end{array}$ \\
\hline \multicolumn{9}{|l|}{ Intermediate regimes: } \\
\hline $\begin{array}{l}\text { Belgium } \\
\text { (German T-bill rate) }\end{array}$ & $1 / 90-12 / 98$ & 0 & $\begin{array}{r}0.34 * * \\
(0.08) \# \#\end{array}$ & $\begin{array}{l}1.02 * * \\
(0.05)\end{array}$ & 0.66 & 0.25 & 0.01 & 108 \\
\hline $\begin{array}{l}\text { Denmark } \\
\text { (German T-bill rate) }\end{array}$ & $1 / 90-12 / 99$ & 2 & $\begin{array}{r}0.28 * * \\
(0.06) \# \#\end{array}$ & $\begin{array}{l}1.26 * * \\
(0.11)\end{array}$ & 0.02 & 0.27 & 0.99 & 118 \\
\hline $\begin{array}{l}\text { Netherlands } \\
\text { (German T-bill rate) }\end{array}$ & $1 / 90-12 / 98$ & 2 & $\begin{array}{l}0.22 * * \\
(0.08) \#\end{array}$ & $\begin{array}{l}1.01 * * \\
(0.04)\end{array}$ & 0.82 & 0.39 & 0.66 & 106 \\
\hline $\begin{array}{l}\text { Portugal } \\
\text { (German T-bill rate) }\end{array}$ & $1 / 90-12 / 99$ & 0 & $\begin{array}{r}0.47 * * \\
(0.07) \# \#\end{array}$ & $\begin{array}{l}1.81 * * \\
(0.12)\end{array}$ & 0.00 & 0.27 & 0.97 & 120 \\
\hline $\begin{array}{l}\text { Spain } \\
\text { (German T-bill rate) }\end{array}$ & $1 / 90-12 / 99$ & 0 & $\begin{array}{l}0.05 * * \\
(0.02)\end{array}$ & $\begin{array}{l}1.53 * * \\
(0.33)\end{array}$ & 0.11 & 0.06 & 0.00 & 120 \\
\hline \multicolumn{9}{|l|}{ Free-floating regimes: } \\
\hline $\begin{array}{l}\text { Australia } \\
\text { (U.S. T-bill rate) }\end{array}$ & $12 / 90-12 / 99$ & 3 & $\begin{array}{r}0.14 * * \\
(0.03) \# \#\end{array}$ & $\begin{array}{l}1.39 * * \\
(0.19)\end{array}$ & 0.05 & 0.62 & 0.98 & 63 \\
\hline $\begin{array}{l}\text { Canada } \\
\text { (U.S. T-bill rate) }\end{array}$ & 1/90-12/99 & 0 & $\begin{array}{r}0.06 * * \\
(0.02) \# \#\end{array}$ & $\begin{array}{l}1.43 * * \\
(0.63)\end{array}$ & 0.49 & 0.12 & 0.64 & 119 \\
\hline $\begin{array}{l}\text { New Zealand } \\
\text { (U.S. T-bill rate) }\end{array}$ & $1 / 90-8 / 99$ & 0 & $\begin{array}{l}0.09 * * \\
(0.04)\end{array}$ & $\begin{array}{l}1.64 * * \\
(0.48)\end{array}$ & 0.19 & 0.11 & 0.11 & 119 \\
\hline $\begin{array}{l}\text { United Kingdom } \\
\text { (U.S. T-bill rate) }\end{array}$ & $1 / 90-12 / 99$ & 2 & $\begin{array}{r}0.24 * * \\
(0.06) \# \#\end{array}$ & $\begin{array}{l}0.72 * * \\
(0.30)\end{array}$ & 0.37 & 0.42 & 0.79 & 86 \\
\hline $\begin{array}{l}\text { Germany } \\
\text { (U.S. T-bill rate) }\end{array}$ & $1 / 90-12 / 99$ & 1 & $\begin{array}{r}0.00 \\
(0.01)\end{array}$ & $\mathrm{N} / \mathrm{A}$ & $\mathrm{N} / \mathrm{A}$ & 0.23 & 0.94 & 119 \\
\hline $\begin{array}{l}\text { Japan } \\
\text { (U.S. T-bill rate) }\end{array}$ & 1/90-12/99 & 5 & $\begin{array}{r}0.01 \\
(0.01)\end{array}$ & N/A & $\mathrm{N} / \mathrm{A}$ & 0.38 & 0.78 & 115 \\
\hline
\end{tabular}


Appendix Table

List of Countries in Sample and Their Exchange Rate Regimes

\begin{tabular}{|c|c|c|c|c|}
\hline \multirow{2}{*}{ Country } & \multicolumn{2}{|c|}{ Period } & \multicolumn{2}{|l|}{ Exchange Regime Classification } \\
\hline & from & to & Narrow Classification & Broad Classification \\
\hline \multirow[t]{6}{*}{ Argentina } & Jan-80 & Mar-81 & Managed floating & Intermediate \\
\hline & Apr-81 & Jun-82 & Independently floating & Floating \\
\hline & Jul-82 & Jun-89 & Managed floating & Intermediate \\
\hline & Jul-89 & Nov-89 & Peg to U.S. dollar & Fixed \\
\hline & Dec-89 & Feb-91 & Independently floating & Floating \\
\hline & Mar-91 & Mar-99 & Peg to U.S. dollar & Fixed \\
\hline \multirow[t]{3}{*}{ Australia } & Oct-74 & Nov-76 & Limited flexibility with respect to a basket & Intermediate \\
\hline & Dec-76 & Nov-83 & Managed floating & Intermediate \\
\hline & Dec-83 & Jun-96 & Independently floating & Floating \\
\hline \multirow[t]{3}{*}{ Austria } & Feb-70 & Aug-71 & Bretton Woods basket peg & Fixed \\
\hline & Sep-71 & Sep-94 & Limited flexibility with respect to a basket & Intermediate \\
\hline & Oct-94 & Dec-98 & Limited flexibility with respect to a cooperative arrangement & Intermediate \\
\hline \multirow[t]{2}{*}{ Belgium } & Feb-70 & Dec-71 & Bretton Woods basket peg & Fixed \\
\hline & Jan-72 & Jan-99 & Limited flexibility with respect to a cooperative arrangement & Intermediate \\
\hline \multirow[t]{3}{*}{ Bolivia } & Jan-95 & Dec-97 & Independently floating & Floating \\
\hline & Jan-98 & Dec-98 & Managed floating & Intermediate \\
\hline & Jan-99 & Mar-99 & Crawling peg & Intermediate \\
\hline Canada & Jan-75 & Mar-99 & Independently floating & Floating \\
\hline Chile & Jan-78 & May-79 & Independently floating & Floating \\
\hline & Jan- 80 & May-82 & Peg to U.S. dollar & Fixed \\
\hline & Jun-82 & Jun-82 & Managed floating & Intermediate \\
\hline & Jul-82 & Dec-98 & Crawling peg to a basket & Intermediate \\
\hline & Jan-99 & Mar-99 & Crawling band & Intermediate \\
\hline Colombia & Mar-95 & Dec-98 & Managed floating & Intermediate \\
\hline & Jan-99 & Mar-99 & Crawling band & Intermediate \\
\hline Costa Rica & Jan-90 & Dec-91 & Managed floating & Intermediate \\
\hline & Jan-92 & Sep-95 & Independently floating & Floating \\
\hline & Oct-95 & Dec-98 & Managed floating & Intermediate \\
\hline & Jan-99 & Mar-99 & Crawling Peg & Intermediate \\
\hline Denmark & Jan-72 & Mar-99 & Limited flexibility with respect to a cooperative arrangement & Intermediate \\
\hline Dominican Republic & Mar-96 & Mar-99 & Managed floating & Intermediate \\
\hline Ecuador & Nov-86 & Sep-94 & Managed floating & Intermediate \\
\hline & Oct-94 & Sep-95 & Crawling peg to a basket & Intermediate \\
\hline & Oct-95 & Dec-98 & Managed floating & Intermediate \\
\hline & Jan-99 & Mar-99 & Crawling band & Intermediate \\
\hline Egypt & Jan-97 & Mar-99 & Managed floating & Intermediate \\
\hline El Salvador & Jan-97 & Mar-99 & Managed floating & Intermediate \\
\hline Finland & Dec-77 & Aug-92 & Limited flexibility with respect to a basket & Intermediate \\
\hline & Sep-92 & Sep-96 & Independently floating & Floating \\
\hline & Oct-96 & Mar-99 & Limited flexibility with respect to a cooperative arrangement & Intermediate \\
\hline Germany & Feb-70 & Apr-70 & Bretton Woods basket peg & Fixed \\
\hline & May-70 & Dec-71 & Independently floating & Floating \\
\hline & Jan-72 & Mar-73 & Bretton Woods basket peg & Fixed \\
\hline & Apr-73 & Mar-99 & Limited flexibility with respect to a cooperative arrangement & Intermediate \\
\hline Greece & Jan-90 & Dec-94 & Managed floating & Intermediate \\
\hline & Jan-95 & Dec-96 & Independently floating & Floating \\
\hline & Jan-97 & Feb-98 & Managed floating & Intermediate \\
\hline & Mar-98 & Mar-99 & Limited flexibility with respect to a cooperative arrangement & Intermediate \\
\hline Guatemala & Jan-97 & Mar-99 & Independently floating & Floating \\
\hline Hong Kong, China & Dec-90 & Mar-99 & Peg to U.S. dollar & Fixed \\
\hline Indonesia & Jan-83 & Jul-98 & Managed floating & Intermediate \\
\hline & Aug-98 & Jul-98 & Independently floating & Floating \\
\hline Ireland & Mar-72 & Apr-72 & Bretton Woods basket peg & Fixed \\
\hline & Jun-72 & Dec-78 & Peg to pound sterling & Fixed \\
\hline & Jan-79 & Mar-99 & Limited flexibility with respect to a cooperative arrangement & Intermediate \\
\hline Israel & Jan-90 & Nov-91 & Limited flexibility with respect to a basket & Intermediate \\
\hline & Dec-91 & Dec-98 & Managed floating & Intermediate \\
\hline & Jan-99 & Mar-99 & Crawling band & Intermediate \\
\hline Italy & Jan-71 & Dec-71 & Bretton Woods basket peg & Fixed \\
\hline & Jan-72 & Jan-73 & Limited flexibility with respect to U.S. dollar & Intermediate \\
\hline & Feb-73 & Dec-78 & Independently floating & Floating \\
\hline & Jan-79 & Aug-92 & Limited flexibility with respect to a cooperative arrangement & Intermediate \\
\hline & Sep-92 & Sep-96 & Independently floating & Floating \\
\hline & Oct-96 & Mar-99 & Limited flexibility with respect to a cooperative arrangement & Intermediate \\
\hline Japan & Jan-70 & Dec-72 & Bretton Woods basket peg & Fixed \\
\hline & Jan-73 & Mar-99 & Independently floating & Floating \\
\hline Korea, Rep. & Aug-76 & Dec-79 & Peg to U.S. dollar & Fixed \\
\hline & Jan-80 & Nov-97 & Managed floating & Intermediate \\
\hline & Dec-97 & Mar-99 & Independently floating & Floating \\
\hline Kuwait & Jan-79 & Mar-99 & Limited flexibility with respect to a basket & Intermediate \\
\hline Lebanon & Jan-82 & Dec-94 & Independently floating & Floating \\
\hline Malaysia & Jan-70 & Jun-72 & Peg to pound sterling & Fixed \\
\hline & Jul-72 & Jun-73 & Peg to U.S. dollar & Fixed \\
\hline & Jul-73 & Aug-75 & Independently floating & Floating \\
\hline & Sep-75 & Mar-93 & Limited flexibility with respect to a basket & Intermediate \\
\hline
\end{tabular}


Appendix Table

List of Countries in Sample and Their Exchange Rate Regimes

\begin{tabular}{|c|c|c|c|c|}
\hline \multirow{2}{*}{ Country } & \multicolumn{2}{|c|}{ Period } & \multicolumn{2}{|l|}{ Exchange Regime Classification } \\
\hline & from & to & Narrow Classification & Broad Classification \\
\hline & Apr-93 & Aug-98 & Managed floating & Intermediate \\
\hline & Sep-98 & Mar-99 & Peg to U.S. dollar & Fixed \\
\hline \multirow[t]{2}{*}{ Mauritius } & Jan-88 & Sep-94 & Limited flexibility with respect to a basket & Intermediate \\
\hline & Oct-94 & Mar-99 & Managed floating & Intermediate \\
\hline \multirow[t]{4}{*}{ Mexico } & Apr-81 & Jun-82 & Managed floating & Intermediate \\
\hline & Jul-82 & Sep-82 & Peg to U.S. dollar & Fixed \\
\hline & Oct- 82 & Nov-94 & Managed floating & Intermediate \\
\hline & Dec-94 & Mar-99 & Independently floating & Floating \\
\hline \multirow[t]{3}{*}{ Netherlands } & Jan-70 & Apr-70 & Bretton Woods basket peg & Fixed \\
\hline & May-70 & Dec-71 & Independently floating & Floating \\
\hline & Jan-72 & Dec-98 & Limited flexibility with respect to a cooperative arrangement & Intermediate \\
\hline \multirow[t]{2}{*}{ New Zealand } & Mar-85 & Feb-85 & Managed floating & Intermediate \\
\hline & Mar-85 & Mar-99 & Independently floating & Floating \\
\hline \multirow[t]{5}{*}{ Norway } & Jan-72 & Nov-78 & Limited flexibility with respect to a cooperative arrangement & Intermediate \\
\hline & Dec-78 & Oct-90 & Limited flexibility with respect to a basket & Intermediate \\
\hline & Nov-90 & Nov-92 & Limited flexibility with respect to a cooperative arrangement & Intermediate \\
\hline & Dec-92 & Apr-94 & Independently floating & Floating \\
\hline & May-94 & Mar-99 & Managed floating & Intermediate \\
\hline Paraguay & Oct-90 & Jun-98 & Independently floating & Floating \\
\hline \multirow[t]{3}{*}{ Philippines } & Oct-81 & Jun-82 & Limited flexibility with respect to U.S. dollar & Intermediate \\
\hline & Jul-82 & Sep-84 & Managed floating & Intermediate \\
\hline & Oct- 84 & Mar-99 & Independently floating & Floating \\
\hline \multirow[t]{3}{*}{ Portugal } & Jan-83 & Sep-90 & Crawling peg to a basket & Intermediate \\
\hline & Oct-90 & Mar-92 & Managed floating & Intermediate \\
\hline & Apr-92 & Mar-99 & Limited flexibility with respect to a cooperative arrangement & Intermediate \\
\hline \multirow[t]{2}{*}{ Singapore } & Aug-73 & Jun-87 & Limited flexibility with respect to a basket & Intermediate \\
\hline & Jul-87 & Mar-99 & Managed floating & Intermediate \\
\hline \multirow[t]{6}{*}{ South Africa } & Feb-70 & Apr-72 & Bretton Woods basket peg & Fixed \\
\hline & May-72 & Sep-72 & Peg to pound sterling & Fixed \\
\hline & Oct-72 & May-74 & Peg to U.S. dollar & Fixed \\
\hline & Jun-74 & Jun-75 & Managed floating & Intermediate \\
\hline & Jul-75 & Jan-79 & Peg to U.S. dollar & Fixed \\
\hline & Feb-79 & Mar-99 & Independently floating & Floating \\
\hline \multirow[t]{5}{*}{ Spain } & Jan-74 & Jan-74 & Bretton Woods basket peg & Fixed \\
\hline & Feb-74 & Dec-75 & Limited flexibility with respect to a basket & Intermediate \\
\hline & Jan-76 & Dec-87 & Managed floating & Intermediate \\
\hline & Jan-88 & May-89 & Independently floating & Floating \\
\hline & Jun-89 & Mar-99 & Limited flexibility with respect to a cooperative arrangement & Intermediate \\
\hline Sweden & Jan-70 & Dec-71 & Bretton Woods basket peg & Fixed \\
\hline & Jan-72 & Jul-77 & Limited flexibility with respect to a cooperative arrangement & Intermediate \\
\hline & Aug-77 & Apr-91 & Limited flexibility with respect to a basket & Intermediate \\
\hline & May-91 & Oct-92 & Limited flexibility with respect to a cooperative arrangement & Intermediate \\
\hline & Nov-92 & Mar-99 & Independently floating & Floating \\
\hline Switzerland & Sep-75 & Sep-78 & Independently floating & Floating \\
\hline & Oct-78 & Dec-79 & Peg to Deutsche mark & Fixed \\
\hline & Jan-80 & Mar-99 & Independently floating & Floating \\
\hline Thailand & Jan-77 & Feb-78 & Peg to U.S. dollar & Fixed \\
\hline & Mar-78 & Jun-81 & Limited flexibility with respect to a basket & Intermediate \\
\hline & Jul-81 & Mar-82 & Managed floating & Intermediate \\
\hline & Apr-82 & Oct-84 & Limited flexibility with respect to U.S. dollar & Intermediate \\
\hline & Nov-84 & Jun-97 & Limited flexibility with respect to a basket & Intermediate \\
\hline & Jul-97 & Jun-98 & Managed floating & Intermediate \\
\hline & Jul-98 & Mar-99 & Independently floating & Floating \\
\hline Turkey & Apr-86 & Dec-98 & Managed floating & Intermediate \\
\hline & Jan-99 & Mar-99 & Crawling peg & Intermediate \\
\hline United Kingdom & Jul-72 & Apr-72 & Bretton Woods basket peg & Fixed \\
\hline & May-72 & Jun-72 & Limited flexibility with respect to U.S. dollar & Intermediate \\
\hline & Jul-72 & Feb-87 & Independently floating & Floating \\
\hline & Mar-87 & Feb-88 & Managed floating & Intermediate \\
\hline & Mar-88 & Sep-90 & Independently floating & Floating \\
\hline & Oct-90 & Jun-92 & Limited flexibility with respect to a cooperative arrangement & Intermediate \\
\hline & Jul-92 & Mar-99 & Independently floating & Floating \\
\hline Uruguay & Dec-92 & Dec-98 & Managed floating & Intermediate \\
\hline & Jan-99 & Mar-99 & Crawling band & Intermediate \\
\hline Venezuela & Apr-96 & Dec-98 & Managed floating & Intermediate \\
\hline & Jan-99 & Mar-99 & Crawling band & Intermediate \\
\hline
\end{tabular}

